\title{
Mirosław Kłusek
}

(Kraków)

\section{Likwidacja wierzytelności instytucji kredytowych z byłego zaboru rosyjskiego przez Państwowy Bank Rolny w Polsce międzywojennej}

$*$

$\mathrm{N}$ a podstawie rozporządzenia Rady Ministrów likwidacja i administracja wierzytelności Banku Włościańskiego, działającego przed I wojną światową na terenie całego zaboru rosyjskiego, i Banku Szlacheckiego funkcjonującego wyłącznie na obszarze województw wschodnich zostały w 1922 r. przekazane Państwowemu Bankowi Rolnemu ${ }^{1}$ Pożyczki zaciągnięte na początku funkcjonowania Banku Szlacheckiego, w okresie od maja 1885 r. do listopada 1889 r. były oprocentowane na 5\% w skali rocznej, a okres spłaty wynosił 36 lat i 7 miesięcy oraz 48 lat 8 miesięcy. Na podstawie Ukazu Cesarskiego do senatu z 12 października 1889 r. oprocentowanie zmniejszono do 4,5\%, a wydany w maju 1890 r. nowy statut Banku Szlacheckiego zmienił dotychczasowe warunki amortyzacji. Wcze-

${ }^{1}$ Rozporządzenie Rady Ministrów z 26 stycznia 1922 w przedmiocie likwidacji spraw byłych rosyjskich państwowych Banków Ziemskich Szlacheckiego i Włościańskiego na obszarze Rzeczypospolitej Polskiej, Dziennik Ustaw Rzeczypospolitej Polskiej (dalej Dz.U. R.P.) 1922, nr 10, poz. 71. Rozporządzenie Rady Ministrów z 7 stycznia 1925 o powierzeniu likwidacji spraw byłych rosyjskich państwowych Banków Szlacheckiego i Włościańskiego Państwowemu Bankowi Rolnemu, Dz.U. R.P. 1925, nr 4, poz. 37. Archiwum Akt Nowych (AAN), Rząd Generalnej Guberni (Rząd GG), sygn. 1378, Bericht über die durchgeführte Prüfungs des Geschäftsteiles III in staatlichen Auftrag vorgenommene Operationen der Staatlichen Agrarbank in Warschau, s. 38. 
śniej udzielone kredyty zostały skonwertowane na nowe okresy umorzenia, z tym że liczono je od pierwotnych terminów wydania. Okresy umorzenia i części składowe półrocznych rat przedstawia tabela $1^{2}$ :

Tabela 1. Okres umorzenia i części składowe półrocznych rat

\begin{tabular}{|c|c|c|c|c|c|}
\hline \multirow{2}{*}{$\begin{array}{c}\text { Okmorzen } \\
\text { w latach }\end{array}$} & \multicolumn{2}{|c|}{ Półroczna rata od 100 jednostek } & Razem & \multirow{2}{*}{ Uwagi } \\
\cline { 2 - 5 } 11 & 2,25 & 3,625 & 0,125 & 6,00 & - \\
\hline 14 & 2,25 & 2,625 & 0,125 & 5,00 & - \\
\hline 20 & 2,25 & 1,625 & 0,125 & 4,00 & - \\
\hline 25 & 2,25 & 1,125 & 0,125 & 3,50 & - \\
\hline 34 i 6 mies. & 2,25 & 0,625 & 0,125 & 3,00 & - \\
\hline 38 i 4 mies. & 2,25 & 0,50 & 0,125 & 2,875 & $\begin{array}{c}\text { Zamitał } \\
\text { okresu 36 lat i 7 miesięcy }\end{array}$ \\
\hline 44 & 2,25 & 0,375 & 0,125 & 2,75 & \\
\hline 51 i 9 mies. & 2,25 & 0,25 & 0,125 & 2,625 & $\begin{array}{c}\text { Zamiast poprzedniego } \\
\text { okresu 48 lat i 8 miesięcy }\end{array}$ \\
\hline 66 i 6 mies. & 2,25 & 0,125 & 0,125 & 2,50 & \\
\hline
\end{tabular}

Kolejne obniżenie oprocentowania kredytów miało miejsce w listopadzie 1894 r. na podstawie Manifestu Cesarskiego na 4\%, a następne na podstawie Ukazu Carskiego z maja 1897 r. na 3,5\%. Ostatnia obniżka dotyczyło tylko starych pożyczek, gdyż nowe wydawano na $4 \% \mathrm{w}$ skali rocznej ${ }^{3}$. W 1906 r. nastąpiła zmiana sposobu udzielania kredytów w Banku Szlacheckim. Zaprzestano wydawania kredytów długoterminowych gotówkowych. Nowe pożyczki udzielano 4,5\% i 5\% listami zastawnymi. Od grudnia 1911 r., aż do przerwania działalności Banku Szlacheckiego przyznawano kredyty tylko w 4,5\% listach zastawnych. Raty półroczne były

2 AAN, Państwowy Bank Rolny (PBR), sygn. 384, PBR Instytucja Centralna wydział likwidacyjny instrukcja nr 25, s. 2.

3 Ibidem, s. 2-3. 
płatne 1 maja i 1 listopada każdego roku . Ich części składowe, z wyjątkiem umorzenia i oprocentowania, były zawsze obliczane od nominału pożyczki ${ }^{5}$. Do wierzytelności Banku Szlacheckiego zaliczone zostały również wierzytelności powstałego jeszcze przed Bankiem Szlacheckim w 1885 r. „Osobowo Otdieła” (Odrębnego Wydziału). Odrębny Wydział Banku Szlacheckiego był instytucją likwidującą kredyty udzielone od roku 1866 przez Towarzystwo Wzajemnego Kredytu Ziemskiego. Do roku 1887 udzielano pożyczki kruszcowe, to znaczy środki pieniężne nie były wydawano w banknotach tylko w monetach. Na podstawie konwersji z 1887 r. wszystkie kredyty kruszcowe zaczęto liczyć jako 4,5\%, z okresem umorzenia 56 lat. Raty półroczne wynosiły 2,05\% nominalnej wysokości długu i były płatne w walucie kredytowej w stosunku: 1 rubel kruszcem równał się 1,50 rubla waluty kredytowej ${ }^{6}$.

Pożyczki w Banku Włościańskim były udzielane na różnych warunkach oraz podlegały dwukrotnej konwersji na mocy Ukazów Carskich z 14 listopada 1894 r. i 6 grudnia 1898 r. Zdecydowana większość kredytów Banku Włościańskiego była rozdysponowana na podstawie Ukazu Carskiego z 18 maja 1882 r. na okres $241 \frac{1}{2}$ lub $341 \frac{1}{2}$ lat przy oprocentowaniu $5,5 \% \mathrm{w}$ skali rocznej, które następnie uległy skonwertowaniu w $1894^{7}$. Konwersja objęła pozostałość niespłaconego długu, który został rozłożony jako nowa pożyczka na okres spłaty na $261 / 2$ i $381 / 3$ lat, o ile dłużnik ze swojej strony nie był zainteresowany rozłożeniem amortyzacji skonwertowanej pożyczki na którykolwiek z innych nowo wprowadzonych okresów spłaty 13, 17 i 513/4 lat. Amortyzacja tych kredytów liczyła się od 1 lipca 1894 r. przy oprocentowaniu 4,5\%. Przy następnej konwersji pożyczek Banku Włościańskiego w 1898 r. okres $261 / 2$ automatycznie został przedłużony do 28 , a $381 / 3$ do $41 \mathrm{lat}^{8}$. Od 1906 r. podobnie jak w przypadku Banku Szlacheckiego zaprzestano udzielania kredytów w gotówce. Nowe pożyczki wydawano w 5\% listach zastawnych (świadectwach banku). Raty płacone przez dłużników zostały obniżone

${ }^{4}$ Ibidem, s. 5.

${ }^{5}$ Nominał pożyczki - wysokość pożyczki bez uwzględniania spłat amortyzacyjnych, zawierających się w ratach.

${ }^{6}$ AAN, PBR, sygn. 384, PBR Instytucja Centralna wydział likwidacyjny instrukcja nr 25, s. 6 .

7 Ibidem, s. 7.

${ }^{8}$ AAN, PBR, sygn. 384, PBR Instytucja Centralna wydział likwidacyjny instrukcja nr 1 z dnia 15 września 1928, s. 7-9. Statut Banku Wtościańskiego, Zbiór Praw Imperium Rosyjskiego, t. XI, cz. 2, wyd. 1912. 
i zrównane dla wszystkich oprocentowań zarówno przy pożyczkach gotówkowych, jak i udzielanych papierami wartościowymi własnej emisji. Brakujące kwoty do pełnych wysokości rat spłacanych Bankowi Włościańskiemu pokrywało państwo rosyjskie. Dłużnik opłacał oprocentowanie umorzone i dodatek na kapitał zapasowy. W 1911 r. zastąpiono udzielanie kredytów w 5\% świadectwach Banku Szlacheckiego na 4,5\%. Okres umorzenia i części składowe rat Banku Szlacheckiego przedstawia tabela $2{ }^{9}$.

Tabela 2. Okres umorzenia i części składowe rat

\begin{tabular}{|c|c|c|c|c|}
\hline \multirow{2}{*}{$\begin{array}{c}\text { Okres umorzenia } \\
\text { w latach }\end{array}$} & \multicolumn{3}{|c|}{ Półroczna rata od 100 jednostek } & \multirow{2}{*}{ Razem } \\
\cline { 2 - 4 } & oprocentowanie & umorzenie & kapitał zapasowy & \\
\hline 13 & 2,25 & 2,885 & 0,2 & 5,335 \\
\hline 18 & 2,25 & 1,835 & 0,2 & 4,285 \\
\hline 28 & 2,25 & 0,910 & 0,2 & 3,360 \\
\hline 41 & 2,25 & 0,435 & 0,2 & 2,885 \\
\hline 55 i 6 miesięcy & 2,25 & 0,210 & 0,2 & 2,660 \\
\hline
\end{tabular}

\section{Przeliczenie pożyczek}

Po odzyskaniu niepodległości przez Polskę likwidacją pożyczek byłych państwowych banków rosyjskich zajmował się zarząd likwidacyjny Głównego Urzędu Ziemskiego $^{10}$. Od 1922 r. zadanie to zostało powierzone Państwowemu Bankowi Rolnemu (PBR), który powołał w tym celu specjalny wydział likwidacyjny przy Instytucji Centralnej ${ }^{11}$. Pozostałe aktywa byłych ban-

9 AAN, PBR, sygn. 384, PBR Instytucja Centralna wydział likwidacyjny instrukcja nr 25, s. 9 .

10 AAN, PBR, sygn. 384, PBR Instytucja Centralna wydział likwidacyjny instrukcja nr 7, tryb załatwiania różnych spraw dotyczących pożyczek byłego rosyjskiego Banku Włościańskiego spłaconych w walucie markowej od roku 1918 do 1 sierpnia 1922 z dnia 15 września 1928, s. 1.

${ }_{11}$ Rozporządzenie Rady Ministrów z 26 stycznia 1922 r. w przedmiocie likwidacji spraw byłych rosyjskich państwowych Banków Ziemskich Szlacheckiego i Włościańskiego na obszarze Rzeczypospolitej Polskiej. Dz.U. R.P. 1922, nr 10, poz.71. Zakres działania wydziału likwidacyjnego PBR dokładnie regulowała instrukcja nr 8. AAN, PBR, sygn. 384, PBR Instytucja Centralna wydział likwidacyjny instrukcja $\mathrm{nr} 8$, tryb postępowania sekcji ogólnej wydziału likwi- 
ków rosyjskich zostały rozdzielone pomiędzy poszczególne urzędy. Majątek własny przejęło Ministerstwo Rolnictwa i Dóbr Państwowych, Ministerstwo Robót Publicznych otrzymało nieruchomości miejskie, natomiast należności jako zwrot ze strony państwa niemieckiego z tytułu nieprawnie pobranych przedterminowych spłat kredytów podczas okupacji tych terenów w kresie I wojny światowej miały wpłynąć do Głównego Urzędu Likwidacyjnego ${ }^{12}$. Do zakresu działalności wydziału likwidacyjnego PBR należały pożyczki udzielone właścicielom majątków ziemskich i drobnym gospodarstwom rolnym zabezpieczone na ich nieruchomościach. Wydział rozpoczął działalność od lipca 1922 r. Jednak wdrożenie właściwej pracy przedłużało się ze względu na brak przepisów dotyczących kwestii regulacji przedwojennych zobowiązań kredytowych. Z tego powodu w sierpniu 1922 r. zostało wstrzymane przyjmowanie rat zaległych, bieżących i przedterminowych spłat pożyczek Banku Włościańskiego ${ }^{13}$. Czynności wydziału ograniczyły się (1923-1924) do udzielania zezwoleń na przewłaszczenia gruntów i prowadzenie urzędowej korespondencji. W tym okresie wydatki związane z utrzymaniem wydziału likwidacyjnego pokrywało Ministerstwo Reform Rolnych, natomiast wydatki rzeczowe pokrywał PBR z własnych funduszy ${ }^{14}$.

Przeliczenie pożyczek zaciągniętych w rosyjskich państwowych Bankach Ziemskich umożliwiły dopiero rozporządzenia Prezydenta Rzeczypospolitej z 14 maja 1924 r. o przerachowaniu zobowiązań prywatnoprawnych i uzupełniające rozporządzenie Prezydenta Rzeczypospolitej z 27 grudnia 1924 r. ${ }^{15}$ Przy zadłużeniach w Banku Szlacheckim za początkową datę przeliczania wzięto 1 maja 1925 r., a jako ostatnio uiszczoną ratę, z powodu braku dokładnych danych, potraktowano ratę listopadową 1914 r. Do pozostałego długu doliczone zostały należne, a nieprzedawnione procenty za okres od

dacyjnego PBR Instytucji Centralnej w zakresie powierzonych jej czynności z dnia15 września 1928 r., s. 1-14. AAN, Rząd GG, sygn. 1378. Bericht über die durchgeführte Prüfungs des Geschäftsteiles III in staatlichen Auftrag vorgenommene Operationen der Staatlichen Agrarbank in Warschau, s. 38.

12 Sprawozdanie Państwowego Banku Rolnego ( PBR) za rok 1925, Warszawa 1926, s. 47. AAN, PBR, sygn. 384. PBR Instytucja Centralna wydział likwidacyjny instrukcja nr 7, tryb załatwiania różnych spraw dotyczących pożyczek byłego rosyjskiego Banku Włościańskiego spłaconych w walucie markowej od roku 1918 do 1 sierpnia 1922 r. z dnia 15 września 1928, s. 2.

13 Ibidem.

14 Sprawozdanie PBR za rok 1923, Warszawa 1925, s. 23; Sprawozdanie PBR za rok 1924, Warszawa 1925, s. 38.

15 Dz.U. R.P. 1924, nr 42, poz. 441 Dz.U. R.P. 1924, nr 110, poz. 987. 
1 maja 1915 r. do 30 kwietnia 1925 r. ${ }^{16}$. Otrzymana kwota w rublach ulegała pomniejszeniu, w zależności od powiatu, w którym była położona posiadłość dłużnika w maju 1924 r. według załączonej poniżej tabeli 3.

Tabela 3. Procentowa redukcja kredytu w rublach w Banku Szlacheckim dla poszczególnych powiatów.

\begin{tabular}{|l|l|l|c|}
\hline \multirow{2}{*}{ Województwo } & \multicolumn{3}{|c|}{ Nazwy powiatów } \\
\cline { 2 - 4 } \multirow{2}{*}{ Białostockie } & $\begin{array}{l}\text { Białystok, Bielsk } \\
\text { Grodno, Wołkowysk } \\
\text { Sokółka }\end{array}$ & \multicolumn{1}{|c|}{$24 \%$} & $15 \%$ \\
\hline Wołyńskie & - & Wszystkie powiaty & - \\
\hline Nowogrodzkie & - & $\begin{array}{l}\text { Nida, Nowogródek, } \\
\text { Słonim }\end{array}$ & $\begin{array}{l}\text { Baranowicze, Nieśwież, } \\
\text { Stołpce, Wołożyn }\end{array}$ \\
\hline Poleskie & - & $\begin{array}{l}\text { Brześć, Drohiczyn, } \\
\text { Kamień Koszyrski, } \\
\text { Kobryń, Kossów, } \\
\text { Pińsk, Prużany, Stolin }\end{array}$ & \multicolumn{1}{|c|}{-} \\
\hline Wileńskie* & - & Wilejka, Wilno-Troki & $\begin{array}{l}\text { Brasław, Dmiłowicze, } \\
\text { Oszmiany, Święciany }\end{array}$ \\
\hline
\end{tabular}

* Powiaty Mołodeczno i Postawy, jako utworzone po dacie rozporządzenia o przeliczeniu, otrzymały strefy procentowe w zależności od powiatu, w którym znajdowała się każda z poszczególnych gmin powiatu. AAN, Państwowy Bank Rolny, sygn. 384. PBR Instytucja Centralna wydział likwidacyjny instrukcja nr 25, s. 13.

Źródło: AAN, Państwowy Bank Rolny, sygn. 384. PBR Instytucja Centralna wydział likwidacyjny instrukcja nr 25, s. 13.

Dopiero kwota w rublach, pomniejszona o odpowiednią wielkość procentową, była przeliczana na złote. Stosunek rubli do złotych przy przeliczaniu dokonywanym przez PBR przedstawiał się w sposób następujący: ${ }^{17}$

${ }^{16}$ Od 1 maja ponieważ raty w Banku Szlacheckim były pobierane z góry, co oznaczało że procenty od kredytów były uiszczone do dnia 30 kwietnia 1915. AAN, Państwowy Bank Rolny, sygn. 384. PBR Instytucja Centralna wydział likwidacyjny instrukcja nr 25, s. 11.

${ }^{17}$ AAN, PBR, sygn. 384, PBR Instytucja Centralna wydział likwidacyjny instrukcja nr 25, s. 13. 
Tabela 4. Stosunek rubli do złotych w przeliczeniu PBR

\begin{tabular}{|c|c|}
\hline Data zaciągnięcia pożyczki & 1 rubel = złotym \\
\hline Do 1 sierpnia 1914 & $2,666 \ldots$ \\
\hline Od 1 sierpnia 1914 do 1 stycznia 1915 & 2,50 \\
\hline W pierwszym półroczu 1915 & 2,27 \\
\hline W drugim półroczu & 2,00 \\
\hline W pierwszym i drugim półroczu 1916 & 2,00 \\
\hline W pierwszym półroczu 1917* & 2,00 \\
\hline
\end{tabular}

* Udzielanie pożyczek przez Bank Szlachecki po pierwszym półroczu 1917 r. było bardzo sporadyczne. AAN, PBR, sygn. 384, PBR Instytucja Centralna wydział likwidacyjny instrukcja nr 25, s. 14.

Źródło: AAN, Państwowy Bank Rolny, sygn. 384. PBR Instytucja Centralna wydział likwidacyjny instrukcja nr 25, s. 16.

Przeliczenie pożyczek z Odrębnego Wydziału Banku Szlacheckiego odbywało się podobnie jak w przypadku samego Banku Szlacheckiego, tylko z niewielkimi różnicami. Za datę przeliczenia przyjęto 1 lipiec 1925 r., a jako ostatnią ratę spłaconą przez dłużnika potraktowano ratę styczniową 1915 r. $^{18}$

W przypadku Banku Włościańskiego przeliczanie pożyczek było zróżnicowane w zależności od siedziby dłużnika. Dla terenów Kresów Wschodnich za datę przeliczenia przyjęto 1 października 1924 r., a za ostatnią spłaconą ratę, z powodu braku dokładnych danych, ratę z kwietnia 1915 r. Raty Banku Włościańskiego były pobierane z dołu, co oznaczało, że procent od pożyczki był uiszczony do 31 marca 1915 r., w związku z czym do pozostałości długu doliczano oprocentowanie za okres od 1 kwietnia 1915 r. do 30 października 1924 r., czyli za dziewięć i pół roku ${ }^{19}$.

Pożyczki dłużników z Kongresówki w okresie panowania waluty markowej były likwidowane przez okupantów i przez działający po zakończeniu I wojny światowej Zarząd Likwidacyjny. Przy ich przeliczaniu uznane zosta-

${ }_{18}$ AAN, PBR, sygn. 384, PBR Instytucja Centralna wydział likwidacyjny instrukcja nr 25, s. 15 .

19 Ibidem, s. 16. 
ły wszystkie spłaty rat i częściowe przedterminowe spłaty w markach - pod warunkiem, że zostały dokonane do 1 sierpnia 1922 roku $^{20}$. W odróżnieniu od Kresów Wschodnich, dłużników Banku Włościańskiego w Kongresówce obowiązywała tabela redukcyjna wysokości przeliczania pożyczek, zamieszczona w tabeli $5^{21}$.

Tabela 5. Redukcja wysokości przeliczania pożyczek dłużników Banku Włościańskiego z terenu Kongresówki

\begin{tabular}{|c|c|c|c|}
\hline \multirow{2}{*}{ Województwo } & \multicolumn{3}{|c|}{ Nazwa powiatu } \\
\hline & $50 \%$ & $42 \%$ & $33 \%$ \\
\hline Warszawskie & $\begin{array}{l}\text { Gostynin, Kutno } \\
\text { Lipno, Łowicz } \\
\text { Nieszawa, Rypin } \\
\text { Włocławek }\end{array}$ & $\begin{array}{l}\text { Błonie, Grójec, Maków, } \\
\text { Mińsk - Mazowiecki, } \\
\text { Płońsk, Pułtusk, Ra- } \\
\text { dzymin, Rawa, Sierpc, } \\
\text { Skierniewice, Sochaczew, } \\
\text { Warszawa }\end{array}$ & Ciechanów, Mława \\
\hline Lubelskie & - & $\begin{array}{l}\text { Garwolin, Janów, Kra- } \\
\text { snystaw, } \\
\text { Lubartów, Lublin, Łu- } \\
\text { ków, Puławy, Siedlce, } \\
\text { Sokołów, Tomaszów, Za- } \\
\text { mość }\end{array}$ & $\begin{array}{l}\text { Biała Podlaska, } \\
\text { Biłgoraj, Chełm, } \\
\text { Radzyń, Włodawa, } \\
\text { Hrubieszów, } \\
\text { Konstatynów, }\end{array}$ \\
\hline Kieleckie & $\begin{array}{l}\text { Będzin, Częstocho- } \\
\text { wa, Miechów, Ol- } \\
\text { kusz }\end{array}$ & $\begin{array}{l}\text { Iłża, Jędrzejów, Kiel- } \\
\text { ce, Końskie, Kozienice, } \\
\text { Opatów,Opoczno, Piń- } \\
\text { czów, Radom, Sando- } \\
\text { mierz, Stopnica, Włosz- } \\
\text { czowa }\end{array}$ & - \\
\hline Białostockie & - & $\begin{array}{l}\text { Wysokie Mazowieckie, } \\
\text { Ostrów }\end{array}$ & $\begin{array}{l}\text { Augustów, Kolno, } \\
\text { Łomża, Ostrołęka, } \\
\text { Szczuczyn, Sejny, } \\
\text { Suwałki }\end{array}$ \\
\hline Łódzkie & Wszystkie powiaty & - & - \\
\hline
\end{tabular}

${ }^{20}$ W rzadkich przypadkach, przy spłatach przedterminowych poświadczonych przez Zarząd Likwidacyjny, termin ten był przesuwany do 1 października 1922 r. AAN, PBR, sygn. 384, PBR Instytucja Centralna wydział likwidacyjny instrukcja nr 25, s. 18.

${ }^{21}$ AAN, PBR, sygn. 384, PBR Instytucja Centralna wydział likwidacyjny instrukcja nr 25, s. 19 . 
Powstała z przeliczenia kwota pożyczki w złotych była rozkładana na raty amortyzacyjne, odpowiadające okresom umorzenia, zgodnie z postanowieniami statutu Banku Szlacheckiego i Banku Włościańskiego. Okres umorzenia otrzymywano po odjęciu liczby lat, podczas których była spłacana pożyczka, od liczby lat wyrażającej okres umorzenia danej pożyczki. Przy każdej półrocznej racie pobierany był dodatek administracyjny na rzecz Państwowego Banku Rolnego w wysokości $0,75 \%$ półrocznie od kwoty długu nominalnego. Dodatek ten stanowił integralną część nowo określonej raty. Niedopuszczalne było dokonywanie spłat zapadłych rat lub przedterminowo pożyczek listami zastawnymi Banku Szlacheckiego lub Banku Włościańskiego $^{22}$. Jako częściowy zwrot kosztów poniesionych przez PBR przy przeliczaniu pożyczek pobierano jednorazowy dodatek, wynosząc w zależności od wysokości pożyczki od 1 do $50 \mathrm{z}^{23}$. Wpływające spłaty po potrąceniu dodatku administracyjnego były przekazywane na konto Funduszu Obrotowego Reformy Rolnej ${ }^{24}$. Na podstawie dokonanych obliczeń ogólna suma pożyczek podlegających likwidacji na terytorium państwa polskiego byłych rosyjskich państwowych Banków Ziemskich została określona na około $39 \mathrm{mln}$ rubli, co w zdecydowanej większości pożyczek po przeliczeniu w relacji $1 \mathrm{ru}$ bel = 2,666 zł dawało około $103 \mathrm{mln} \mathrm{zk}^{25}$. Jak z tego wynika, kwota ta w stosunku do stanu z $1914 \mathrm{r}$. roku uległa poważnej redukcji ${ }^{26}$.

22 Rozporządzenie Prezydenta Rzeczypospolitej z 27 grudnia 1924 r. Dz.U. R.P. 1924, nr 115, poz. 1031

${ }_{23}$ AAN, PBR, sygn. 384, PBR Instytucja Centralna wydział likwidacyjny instrukcja nr 25, s. $20-21$.

${ }^{24}$ AAN, Rząd GG, sygn. 1378, Bericht über die durchgeführte Prüfungs des Geschäftsteiles III in staatlichen Auftrag vorgenommene Operationen der Staatlichen Agrarbank in Warschau, s. 38.

25 Rozporządzenie Prezydenta Rzeczypospolitej z 27 grudnia 1924 r uzupełniające rozporządzenie z 14 maja 1924 r. o przerachowaniu zobowiązań prywatnoprawnych w stosunku do wierzytelności z pożyczek udzielanych przez byłe rosyjskie Banki Ziemski oraz byłe rosyjskie Towarzystwa kredytowe miejskie, których zarządy miały siedzibę poza granicami Państwa Polskiego. Dz.U. R.P. 1924, nr 115, poz. 1025, $\$ 1,2,3,4$, 6 i 7.

${ }^{26}$ Stan zadłużenia ziem zaboru rosyjskiego wobec Banku Włościańskiego na dzień 1 stycznia 1914 r. kształtował się w następujący sposób: obszar byłej Kongresówki - 13 mln rubli, a województwa wschodnie $60 \mathrm{mln}$ rubli. Natomiast kredyty zaciągnięte w Banku Szlacheckim dotyczyły tylko ziem województw wschodnich i wynosiły $57 \mathrm{mln}$ rubli. W sumie ogólna kwota należności wobec rosyjskich banków wynosiła $130 \mathrm{mln}$ rubli. Był to dług zasadniczy wraz z bieżącymi należnościami ubocznymi i po potrąceniu zrealizowanych pożyczek po kursie $1 \mathrm{ru}-$ bel = 2,16 mk. Sprawozdanie PBR za rok 1925, Warszawa 1926, s. 48.

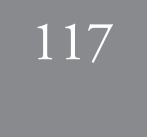


Przeliczanie konkretnych pożyczek wymagało wcześniejszego przeprowadzenia szeregu prac zmierzających do ujawnienia wysokości zadłużenia. Wszystkie dokumenty i akta dotyczące działalności tych instytucji kredytowych na ziemiach polskich, zgodnie z postanowieniami traktatu ryskiego, miały zostać niezwłocznie przekazane przez rząd Rosji bolszewickiej (potem Związku Socjalistycznych Republik Radzieckich) stronie polskiej. Z powodu niewywiązywania się ze swoich zobowiązań przez stronę bolszewicką, Państwowy Bank Rolny był zmuszony do rozpoczęcia żmudnej pracy - mającej na celu ujawnienia stanu faktycznego wierzytelności. Prowadzone dochodzenia były bardzo trudne, szczególnie w województwach wschodnich. $\mathrm{Na}$ tych terenach do wybuchu I wojny światowej gospodarstwa rolne nie posiadały założonych ksiąg hipotecznych. Podstawowym źródłem były rejestry w archiwach Starszych Notariuszy. Znajdujące się tam sprawy przewłaszczeniowe i obciążenia nieruchomości, niestety, prowadzone były chronologicznie według dat zawierania aktów i nie posiadały skorowidzów. Kolejnym utrudnieniem na drodze ustalania zadłużeń był brak dokładnych danych w odniesieniu do właścicieli poszczególnych gospodarstw rolnych oraz fakt dokonywania w międzyczasie licznych alienacji, które były uwidaczniane $\mathrm{w}$ różnorodnych rejestrach archiwów ${ }^{27}$. W związku z tym PBR w swoich ustaleniach musiał się oprzeć na analizie nie tylko dostępnych ksiąg notarialnych i rejestrów, ale również i innych dokumentów urzędowych ${ }^{28}$. Specjalnie do realizacji tego zadania powołane zostały sekcje likwidacyjne, w Grodnie dla zbadania archiwów sądowych w Grodnie i Białymstoku, Łucku dla Łucka i Równego, Pińsku i Wilnie dla Wilna i Nowogrodu. Lokalne sekcje likwidacyjne zebrany materiał przesyłały do centrali w Warszawie, która uzupełniała go i na tej podstawie wysyłała dłużnikom nakaz płatniczy. Ponadto na ziemiach wschodnich Polski w związku z przeprowadzoną parcelacją, wydział likwidacyjny PBR utworzył specjalny referat parcelacyjno-segregacyjny.

27 Ibidem, s. 47.

28 Źródłami służącymi do ujawnienie stanu zadłużenia w Banku Szlacheckim i jego Odrębnym Wydziale były archiwa notarialne sądów okręgowych w Grodnie, Białymstoku, Wilnie, Nowogródku, Pińsku, Łucku i Równem, rosyjskie wydawnictwo urzędowe „Prawitielstiennyj Wiestnik” - dział ogłoszeń o licytacji majątków zadłużonych w Banku Szlacheckim, archiwa urzędów skarbowych, archiwa okręgowych Urzędów Ziemskich oraz archiwa wojewódzkich wydziałów rolnictwa i weterynarii. AAN, PBR, sygn. 384, PBR Instytucja Centralna wydział likwidacyjny instrukcja nr 11, tryb postępowania przy załatwianiu spraw związanych z ujawnianiem pożyczek były rosyjskiego Banku Szlacheckiego i jego Odrębnego Wydziału z 15 dnia września 1928, s. 1. 
Jego zadanie polegało na rozsegregowaniu wierzytelności Banku Szlacheckiego pomiędzy faktycznych właścicieli już rozparcelowanych części oraz przyszłych nabywców parcelowanych gruntów.

Tryb postępowania przy zakładaniu kart dla każdej pożyczki byłych rosyjskich państwowych banków był dokładnie określony ${ }^{29}$. Bardzo często dłużnicy po otrzymaniu wezwania wnosili reklamację, powołując się na zmiany w stanie zadłużenia spowodowane częściową alienacją lub parcelacją zadłużonej ziemi. W związku z reklamacjami PBR został zobowiązany do wykonania szczegółowego badania podstaw prawnych każdej sprawy, oraz do odpowiedniego zastosowania byłych ustaw rosyjskich i ustaw wydanych już po odzyskaniu niepodległości przez Polskę. Do najważniejszych polskich przepisów prawnych, mających bezpośredni wpływ na wierzytelności wobec byłych banków rosyjskich, należała ustawa o przejęciu na rzecz państwa pewnych obszarów ziemskich w województwach wschodnich, ustawa o uwłaszczeniu czynszowników i drobnych dzierżawców i ustawa o uregulowaniu serwitutów. Wszystkie te ustawy dokonywały częściowego zwolnienia z obciążeń majątków ziemskich ${ }^{30}$. Państwowy Bank Rolny dokumenty dotyczące dłużników Banku Włościańskiego przesyłał do archiwum skarbowego w Warszawie, celem dołączenia ich do akt tego banku. Akta rosyjskich spółek, które pożyczek nie spłaciły, pozostawały w archiwum wydziału likwidacyjnego Instytucji Centralnej PBR ${ }^{31}$.

$\mathrm{Na}$ koniec 1925 r. ujawnione i przeliczone wierzytelności byłych banków rosyjskich wynosiły: 17863 pożyczki - na kwotę 49,6 mln zł i przedstawiały się w następujący sposób: Bank Włościański na terenie Kongresówki - pożyczek 4285 na kwotę 8,5 mln zł, na terenie województw wschodnich pożyczek 11889 na kwotę 22,4 mln zł, Bank Szlachecki - woj. wschodnie 1521 pożyczek na sumę 18,2 mln zł, Odrębny Wydział Banku Szlacheckiego - woj. wschodnie - 168 pożyczek na kwotę 461 tys. zł. Roczna wysokość rat

${ }^{29}$ AAN, PBR, sygn. 384, PBR Instytucja Centralna wydział likwidacyjny instrukcja nr 9, tryb postępowania przy zakładaniu teczek dla każdej danej pożyczki byłych rosyjskich banków ziemskich z dnia 15 września 1928, s. 1-4.

30 Wierzytelności b. Banku Szlacheckiego i b. Banku Wtościańskiego, „Rolnik Ekonomista. Dwutygodnik”, Organ Związku Polskich Organizacji Rolniczych, 1927, t. II, s. 285-286. Przy artykule brak autora. Sprawozdanie PBR za rok 1925, Warszawa 1926, s. 49.

31 AAN, PBR, sygn. 384, PBR Instytucja Centralna wydział likwidacyjny instrukcja $\mathrm{nr} 7$, tryb załatwiania różnych spraw dotyczących pożyczek byłego rosyjskiego Banku Włościańskiego spłaconych w walucie markowej od roku 1918 do 1 sierpnia 1922 r. z dnia15 września 1928, s. 3-4. 
amortyzacyjnych od powyższego zadłużenia została określona na 3,2 mln zł. Kwota ta zawierała już dodatek administracyjny wynoszący 745 tys. zł. W związku z tym, że około 1/3 majątków obciążonych długiem byłego Banku Szlacheckiego została przejęta przez państwo oraz faktu częściowego umorzenia lub całkowitej spłaty niektórych kredytów do ewakuowanych oddziałów byłych banków rosyjskich, dokonano redukcji i raty amortyzacyjne za rok 1925 określono w przybliżeniu na $2 \mathrm{mln}$ zł. Dopuszczano także możliwość częściowej lub całkowitej przedterminowej spłaty pożyczek ${ }^{32}$. Na podstawie rozesłanych nakazów płatniczych do PBR wpłynęło 686 tys. zł. Na Fundusz Obrotowy Reformy Rolnej zostało przekazane 468 tys. zł, natomiast resztę Bank, jako należną mu z tytułu kosztów administracyjnych, przelał do funduszów własnych. Tak niski wpływ należności wynikał z przeciągania się procesu ujawniania i ustalania wysokości pożyczek, w większości przypadków były one zakończone dopiero pod koniec 1925 r. oraz klęski nieurodzaju na ziemiach wschodnich. Dłużnicy Banku Włościańskiego z tego powodu otrzymali prolongaty ${ }^{33}$.

W stosunku do opornych dłużników stosowano przymusową egzekucję należności, polegającą na ściąganiu bezspornych należności skarbowych z ruchomości dłużników. W przypadku drobnych gospodarstw egzekucje te na mocy specjalnej ulgi były zawieszane ${ }^{34}$. Dla uruchomienia egzekucji nieruchomości Banku Szlacheckiego znowelizowano przepisy licytacyjne tego banku. Rozporządzenie wydane przez centralne władze państwowe kompleksowo i dokładnie określało procedurę licytacyjną wobec wierzytelności wszystkich byłych rosyjskich instytucji kredytowych ${ }^{35}$. Dzięki czemu w 1927 r. roku wobec 25\% przypadków ociągających się dłużników została zastosowana egzekucja z ruchomości ${ }^{36}$.

W związku z bardzo trudną sytuacją, w jakiej znalazło się rolnictwo podczas kryzysu, postanowiono przyjść z pomocą także dłużnikom byłych

32 AAN, Państwowy Bank Rolny, sygn. 384, PBR Instytucja Centralna wydział likwidacyjny instrukcja nr 5 tryb załatwiania spraw częściowego i całkowitego spłacania pożyczek byłego rosyjskiego Banku Włościańskiego z dnia 15 września 1928, s. 1-6. Sprawozdanie PBR za rok 1925, Warszawa 1926, s. 48.

33 Wierzytelności b. Banku Szlacheckiego, s. 286. Sprawozdanie PBR za rok 1925, Warszawa 1926 , s. 48.

34 AAN, PBR, sygn. 384, PBR Instytucja Centralna wydział likwidacyjny instrukcja nr 4 z dnia15 września 1928, s. 1-2.

35 Sprawozdanie PBR za rok 1925, Warszawa 1926, s. 49.

36 Sprawozdanie PBR za rok 1927, Warszawa 1928, s. 69. 
rosyjskich banków. W tym celu wydano w 1932 r. rozporządzenie Prezydenta $\mathrm{RP}^{37}$. Na jego podstawie PBR wprowadził ulgi w spłacie likwidowanych należności. Dłużnicy, którzy w wyznaczonym terminie uregulowali raty za 1932 r., mogli liczyć na odroczenie i rozterminowanie na wiele lat zaległych należności, począwszy od 1933 r. Odroczone zaległości były rozłożone na drobne raty, płatne każdego roku wraz z drugą ratą amortyzacyjną pożyczek, w granicach okresu amortyzacyjnego. Dłużnikom rzetelnie wywiązującym się w latach 1932 i 1933 ze spłaty w terminie bieżących rat amortyzacyjnych i odroczonych zaległości darowano naliczone, a nie pobrane kary za zwłokę. PBR został również upoważniony do odroczenia spłaty bieżących i sprolongowanych rat, jeżeli dłużnik znalazł się w wyjątkowej sytuacji, np. klęska żywiołowa $^{38}$. Następnie, zgodnie z paragrafem 9 rozporządzenia z października 1934 r., pożyczki uległy konwersji ${ }^{39}$. Począwszy od 1 lipca 1935 r. maksymalny okres spłaty został ustalony na 56 lat, przy oprocentowaniu 4,5\% w skali rocznej wraz z kosztami administracyjnymi. Konwersja dotyczyła wszystkich należności z tytułu pożyczek Banku Szlacheckiego i Banku Włościańskiego udzielonych gospodarstwom o wielkości areału do $50 \mathrm{ha}^{40}$. Nie obejmowała kredytów Banku Szlacheckiego, które obciążały gospodarstwa powyżej 50 ha. W stosunku do nich konwersja mogła być zastosowana według uznania Państwowego Banku Rolnego ${ }^{41}$. Na podstawie tych przepisów w 1936 r. skonwertowano 59191 pożyczek na kwotę 56271 tys. zł na okres maksymalny (56 lat), przy oprocentowaniu 4,5\% w skali rocznej. Do grupy scaleniowo-melioracyjnej Funduszu Obrotowego Reformy Rolnej ${ }^{42}$ przeniesiono

${ }^{37}$ Rozporządzenie z dnia 21 czerwca 1932 r., Dz.U. RP 1932, nr 52, poz. 494.

38 Sprawozdanie PBR za rok 1932, Warszawa 1933, s. 55-56.

39 Rozporządzenie Prezydenta Rzeczypospolitej z dnia 24 października 1934 r., Dz.U. RP 1934, Nr 94, poz. 842.

40 Szerzej na temat konwersji zadłużenia rolniczego i w Państwowym Banku Rolnym zob.: M. Kłusek, Dokumenty do dziejów Państwowego Banku Rolnego. Tom I: 1938-1944, Łódź 2009, s. 23-39. idem, Kredyt krótkoterminowy Państwowego Banku Rolnego w Polsce międzywojennej, „Roczniki Naukowe Stowarzyszenia Ekonomistów Rolnictwa i Agrobiznesu”, t. X, z. 1, Warszawa 2008, s. 173-174; idem, Konwersja zadtużenia rolniczego jako element walki państwa z kryzysem w rolnictwie w Polsce międzywojennej, „, Roczniki Naukowe Stowarzyszenia Ekonomistów Rolnictwa i Agrobiznesu”, t. XI, z. 2, Warszawa 2009, s. 104-110. M. Nowak, Państwowy Bank Rolny w Drugiej Rzeczypospolitej, Kraków 1983, s. 93-111.

${ }^{41}$ AAN, Rząd GG, sygn. 1378, Bericht über die durchgeführte Prüfungs des Geschäftsteiles III in staatlichen Auftrag vorgenommene Operationen der Staatlichen Agrarbank in Warschau, s. 39. Sprawozdanie PBR za rok 1934, Warszawa 1935, s. 56.

42 Fundusz Obrotowy Reformy Rolnej powstały w 1928 r. miał służyć realizacji reformy 
1759 pożyczek na sumę 518 tys. zł. Celem tego zabiegu było połączenie ich w jeden dług i wspólne skonwertowanie z pożyczkami komasacyjnymi, obciążającymi te same grunta. Państwowy Bank Rolny do konwersji nie zakwalifikował kredyty obciążające gospodarstwa powyżej 50 ha. Było ich 214 na sumę 3994 tys. zł, w tym 15 pożyczek na kwotę 307 tys. zł zabezpieczonych na nieruchomościach przejętych przez Skarb Państwa ${ }^{43}$.

Stan i tempo likwidacji należności z tytułu wierzytelności rosyjskich państwowych Banków Ziemskich do 1939 r. przedstawia tabela 6. Z tego wynika, że Państwowy Bank Rolny potrafił zidentyfikować mniej niż połowę wszystkich należności wobec Banku Włościańskiego i Banku Szlacheckiego ${ }^{44}$.

Tabela 6. Stan i tempo likwidacji należności z tytułu wierzytelności rosyjskich

\begin{tabular}{|c|c|c|c|c|c|c|}
\hline \multirow{2}{*}{ Stan na dzień } & \multicolumn{2}{|c|}{ Razem } & \multicolumn{2}{c|}{$\begin{array}{c}\text { Pożyczki } \\
\text { skonwertowane }\end{array}$} & \multicolumn{2}{c|}{$\begin{array}{c}\text { Pożyczki } \\
\text { nieskonwertowane }\end{array}$} \\
\cline { 2 - 8 } & $\begin{array}{c}\text { liczba } \\
\text { pożyczek }\end{array}$ & $\begin{array}{c}\text { kwota } \\
\text { w tys. zł }\end{array}$ & $\begin{array}{c}\text { liczba } \\
\text { pożyczek }\end{array}$ & $\begin{array}{c}\text { Kwota } \\
\text { w tys. zł }\end{array}$ & $\begin{array}{c}\text { liczba } \\
\text { pożyczek }\end{array}$ & $\begin{array}{c}\text { kwota } \\
\text { w tys. zł }\end{array}$ \\
\hline 1 stycznia 1939 & 78243 & 59600 & 78040 & 55365 & 203 & 4235 \\
\hline 1 kwietnia 1939 & 78163 & 59033 & 77962 & 54925 & 202 & 4108 \\
\hline 1 lipca 1939 & 77884 & 59692 & 77685 & 55601 & 199 & 4091 \\
\hline
\end{tabular}

Źródło: Archiwum Państwowe w Kielcach (AP w Kielcach), Państwowy Bank Rolny (PBR), sygn. 41, Sprawozdanie z działalności Państwowego Banku Rolnego za I kwartał 1939, s. 56-57. AP w Kielcach, PBR, sygn. 42, Sprawozdanie z działalności Państwowego Banku Rolnego za II kwartał 1939, s. 52-53.

Podczas II wojny światowej od dłużników Banku Szlacheckiego i Banku Włościańskiego, którzy znaleźli się na terenie Generalnej Guberni, w dalszym ciągu były ściągane należności. Na koniec grudnia 1941 r. ogólna liczba pożyczek wynosiła 9185 na łączną kwotę prawie 6 mln zł. Dłużnicy

agrarnej. Wyposażony został przez Skarb Państwa w dotacje w postaci gotówki oraz zapasu ziemi. S. Zalewski, Ewolucja kredytu dtugoterminowego ziemskiego w Polsce, Warszawa 1938, s. 113.

43 AAN, Rząd GG, sygn. 1378, Bericht über die durchgeführte Prüfungs des Geschäftsteiles III in staatlichen Auftrag vorgenommene Operationen der Staatlichen Agrarbank in Warschau, s. 39. Sprawozdanie PBR za rok 1936, Warszawa 1937, s. 74.

${ }^{44}$ M. Nowak, op. cit., s. 50. 
uiszczali zapadłe raty oraz dokonywali częściowych, a nawet przedterminowych spłat na poziomie nie odbiegającym od pozostałych grup dłużników Funduszu Obrotowego Reformy Rolnej ${ }^{45}$. Po zakończeniu II wojny światowej większa część wierzytelności Banku Włościańskiego i Banku Szlacheckiego znalazła się poza nowymi granicami Polski. Na terenie kraju pozostały tylko pożyczki byłego Banku Włościańskiego oraz drobny odsetek byłego Banku Szlacheckiego w województwie białostockim. W wyniku działań wojennych prawie wszystkie dokumenty tej grupy wierzytelności uległy zniszczeniu. Konieczne było przeprowadzenie żmudnych prac mających na celu odtworzenie kont dłużników ${ }^{46}$. Po ich wykonaniu i wydaniu przepisów regulujących spłaty kredytów Funduszu Obrotowego Reformy, dłużnicy byłego Banku Włościańskiego i Banku Szlacheckiego zostali zobowiązania do spłaty należności do Państwowego Banku Rolnego.

\section{Liquidation of loans of credit institutions from the former Russian partition of Poland by the National Bank of Agriculture in the interwar Poland}

\section{(Summary)}

After regaining independence of Poland in 1918, the General Institution of Mansion was responsible for the liquidation of former national Russian banks. Since 1922 liquidation and administration of liabilities of the Mansion Bank, that had been functioning in the area of Russian partition before the World War I, and the Noble Bank, which was only acting in eastern voivodeship, has been a task of the National Bank of Agriculture. According to President's of Poland ordinances from 1924, an overall sum of loans of former Russian Mansion Banks that was to liquidate, was estimated for about $39 \mathrm{mln}$ rubels. In situation when 1 rubel was equal 2,666 zloty, it gave the sum of about 103 mln zlotys. Meanwhile, a real sum of liabilities of former Russian banks was about 50 mln zlotys, which was revealed afterwards.

The National Bank of Agriculture, that liquidated and administered of former Russian banks loans, was functioning not only in the interwar period. Dur-

45 AAN, PBR, sygn. 413/1, Sprawozdanie Państwowego Banku Rolnego za okres od 1 lipca do 31 grudnia 1941 z terenu Generalnej Guberni, s. 66-68.

46 AAN, PBR, sygn. 77, Sprawozdanie Państwowego Banku Rolnego za 1945 r., s. 21. AAN, PBR, sygn. 78, Sprawozdanie Państwowego Banku Rolnego za 1946 r., s. 55. 
ing Nazis' occupation there were taken money from debtors of Noble Bank and the Włościański’s Bank, who stayed in the General Government, as well. After World War II, liabilities of already non-existing Mansion Bank, in that time in new borders of Poland, as well as small part of the former Noble Bank in Białostockie Voivodeship, was pointed to liquidation. Because of military operations almost all documents that proved liabilities had been destroyed. In that situation it was necessary to re-establish the debtors' accounts. After accounts were known and necessary laws were accepted, the debtors of the Noble Bank and the Mansion Bank were obligated to pay back liabilities to the National Bank of Agriculture. 